\title{
ON THE METAPHORICAL CONCEPTUALIZATION OF CONTRASTING EMOTIONAL EXPERIENCES: THE CASE OF PRIDE AND SHAME IN ENGLISH AND SERBIAN
}

\begin{abstract}
Set against the theoretical background of Conceptual Metaphor Theory, this paper compares the conceptualization of positive self-evaluation emotions and those originating from negative self-evaluation in English and Serbian. The findings show that these contrasting emotion concepts predominantly tend to be characterized by an independent and unique metaphoric conceptualization, i.e. that emotions such as pride and shame are only rarely structured via pairs of opposing metaphors (e.g. the UP/ BIG-DOWN/SMALL contrast). Other than that, although there is an asymmetry at a high level of generality (e.g. the PRECIOUS POSSESSION-UNDESIRABLE OBJECT opposition), the specific-level metaphors are characterized by a unique elaboration of the metaphorical "possession of the object scenario". On a more general level, negative self-evaluation emotions are found to be more strongly associated with the image of a reified emotion coming into forcible contact with the experiencer, thereby indicating that some of the most salient metaphors structuring negative self-conscious emotions exhibit a higher degree of entrenchment in the body.
\end{abstract}

Key words: pride, shame, conceptual metaphor, contrasting emotional states, English, Serbian

\section{Introduction}

This paper explores the metaphorical conceptualization of a special subset of emotions in English and Serbian - the so-called self-conscious emotions, which have been recognized as a distinct category of emotional experience as these emotions, unlike basic emotions, inherently derive from self-evaluative processes (Tangney and Fischer 1995; Leary 2004; Tracey and Robins 2004). In the current emotion literature (e.g. Tracey and Robins 2004), a clear distinction is drawn between two central self-conscious emotions which stand in opposition to one another - pride and

* Faculty of Philology, University of Belgrade, Studentski trg 3, 11000 Belgrade, Serbia; e-mail: andrijana. brocic@fil.bg.ac.rs 
shame. Since pride and shame are perceived as antonymous emotion concepts, the aim of this analysis is to shed light on the unique characteristics of the metaphorical conceptualization of emotion concepts that presuppose positive self-evaluation as opposed to those originating from negative self-evaluation, thereby also providing some insight into the types of metaphors involved in the construction of contrasting emotional states more generally, and whether (and to what degree) such emotional states are structured in terms of opposing metaphors. ${ }^{1}$

The analysis was performed within the theoretical framework of Conceptual Metaphor Theory (henceforth CMT; Lakoff and Johnson 2003[1980]), which views metaphor as an indispensable cognitive mechanism whereby we understand one conceptual domain (target domain; this domain is usually (but not necessarily) abstract) by means of another conceptual domain, the so-called source domain, which is tangible and more clearly delineated in everyday experience ${ }^{2}$. Being primarily conceptual phenomena, conceptual metaphors only indirectly emerge as metaphorical linguistic expressions, or in the words of Lakoff and Johnson 2003[1980]: 6), metaphors as linguistic expressions are possible precisely because there are metaphors in a person's conceptual system". By way of illustration, examples such as pride awakens or shame burned within her would be regarded as linguistic instantiations of the metaphors PRIDE IS A LIVING BEING/ANIMATE ENTITY and SHAME IS FIRE respectively.

The conceptual representation of emotions, particularly regarding emotionrelated metaphors, has received considerable attention within cognitive linguistic research, and numerous aspects pertaining to conceptual metaphors structuring emotion concepts have been discussed in great detail. For instance, given that the issue of the motivation of conceptual metaphors (Grady 1999) has been one of the most important research questions in cognitive linguistics, issues such as the experiential grounding of emotion metaphors as well as their potential universality and variation across languages and cultures have been debated. To illustrate, the generic-level metaphor ANGER IS A HOT FLUID IN A CONTAINER has been found to structure anger in a large number of different languages, its potential universality being accounted for by its entrenchment in the human body, i.e. the correlation between our experience of anger and the potentially universal bodily reactions - body heat and an increase in body temperature - that anger typically entails (Lakoff 1987; Kövecses 2005). In this respect, the cross-linguistic differences and similarities in the metaphoric conceptualization of emotions have been the subject of a number of cognitive linguistic studies (e.g. Kövecses 2005; Kosanović

\footnotetext{
${ }^{1}$ This paper is based on a large-scale study into the conceptualization of self-conscious emotions in English and Serbian (Broćić 2018a).

${ }^{2}$ For a detailed discussion of the cognitive linguistic view of conceptual metaphors see e.g. Klikovac (2004), Kövecses (2010[2002]).
} 
2009, 2016; Dziwirek and Lewandowska-Tomaszczyk 2010; Ogarkova and Soriano 2014a, 2014b; Broćić 2018a). Kövecses (1998, 2000, 2008) further discusses the issue of the scope of metaphor, i.e. whether there are any emotion-specific source domains, claiming that all source domains have a scope of application that extends beyond the domain of emotions, whereas Soriano (2015) and Ogarkova and Soriano (2018) argue that CMT-based studies of emotion concepts can make a major contribution to disciplines such as cross-cultural emotion psychology, or, more generally, the affective sciences. As regards the metaphoric conceptualization of opposing emotional states in particular, Köveces (2000: 44) analyses the source domains of UP-DOWN, LIGHTDARK, WARM-COLD and VALUABLE-NONVALUABLE in the context of the "positive-negative" evaluation of particular emotions, claiming that "...these source domains only apply to happiness-sadness, pride-shame, and affection-indifference, which are inherently positive or negative". On the other hand, Stefanowitsch's corpus-based analysis (2006: 52-54) suggests that emotions such as happiness and sadness are not structured via pairs of opposing metaphors, for instance, the source domains of LIGHT Vs. DARKNESS or PAIN vs. PHYSICAL WELLBEING. As argued by Stefanowitsch (2006), HAPPINESS and SADNESS are conceptualized separately ${ }^{3}$.

As previously stated, the analysis presented in this paper will further explore the issue of the metaphoric structure of contrasting emotional states, with special emphasis on PRIDE and SHAME in English and Serbian. In addition to pride and shame (ponos and stid in Serbian), the analysis also included two representative sets of lexemes that are listed as synonymous with pride and shame in the authoritative English and Serbian dictionaries:

1) the PRIDE domain: pride, dignity, self-esteem, self-respect, arrogance, ego, vanity in English; ponos (pride), dostojanstvo (dignity), samopoštovanje (self-respect), gordost (pride), oholost (conceit), nadmenost (haughtiness), arogancija (arrogance), sujeta (vanity), ego (ego) in Serbian

2) the SHAME domain: shame, embarrassment, guilt in English; stid (shame/ embarrassment), sram (shame), sramota (shame) in Serbian.

The linguistic data used - or more specifically, the linguistic examples containing the aforementioned target domain lexis - were excerpted from general corpora, and comprise 6,241 examples in English and 6,930 in Serbian. The English examples were gathered from the British National Corpus (henceforth BNC), whereas the Serbian data were excerpted from the electronic Korpus savremenog srpskogjezika (henceforth KSSJ, [Corpus of the Contemporary Serbian Language]). The underlying conceptual mappings were subsequently formulated based on the meanings of the

\footnotetext{
${ }^{3}$ It is important to emphasize, however, that Stefanowitsch interprets his findings based on whether the pertinent conceptual mappings are frequent in a statistically significant way.
} 
lexical items collocating with the noun lexemes denoting the target emotion concepts (e.g. pride reawakens, ponos se budi > PRIDE IS A LIVING BEING/AN ANIMATE ENTITY). In addition to the previously mentioned corpus data, the linguistic realizations of the metaphors based on UP/BIG, i.e. DOWN/SMALL were gathered from a larger-scale study into the role of VERTICALITY and PHYSICAL SIZE in the conceptualization of self-conscious emotions (Broćić 2014).

This paper is intended to give a broad and concise overview of the most salient metaphors involved in the construction of these emotions following the basic classification of the identified metaphors into those with the source domains of BIG/ UP, i.e. SMALL/DOWN, AN OBJECT, SUBSTANCE and A LIVING BEING/ANIMATE ENTITY ${ }^{4}$. A full discussion of the similarities and differences in the conceptualization of self-conscious emotions in English and Serbian at conceptual, linguistic and cultural levels is provided in Broćić (2018a). Additionally, the findings presented in some of the sections are partly based on Broćić $(2014,2018 b, 2019)$.

\section{Results}

\subsection{The BIG/UP-SMALL /DOWN contrast}

Firstly, the metaphors based on the concepts BIG/UP as opposed to SMALL/DOWN, such as TO BE (EXCESSIVELY) PROUD IS TO BE UP/ $\mathrm{BIG}^{5}$ as against TO FEEL SHAME IS TO BE DOWN/SMALL, constitute a clear-cut case of contrasting metaphors structuring opposite self-conscious emotions. In both languages, there are a wide range of diverse (usually idiomatic) expressions motivated by these generic-level metaphors which evoke images of the experiencer becoming physically big/ bigger/taller, i.e. increasing in size in the domain of PRIDE. In the domain of SHAME, by contrast, the experiencer is depicted as shrinking in size or sinking into the ground:

E:

1) To swell, grow with pride/puffed-up, plump, fat with conceit/to be too big for his boots/to ride one's high horse/with one's nose in the air

2) Initially I felt small and ashamed of myself

$\mathrm{S}$ :

3) Rasti od ponosa ('grow with pride')/Nosem parati oblake (lit. rend clouds with one's nose)/More nekome nije do kolena (lit. the sea can't reach higher than one's knees)/Gledati druge s visine ('to look down on others')

\footnotetext{
${ }^{4}$ The prominence of a particular conceptual mapping is here established primarily on the basis of the diversity of the pertinent metaphorical instantiations, and, only secondarily, with respect to the frequency of these expressions in the corpora (see Broćić 2018a).

${ }^{5}$ Kövecses (2000) lists THE CONCEITED PERSON IS UP/HIGH and CHEST OUT/ERECT POSTURE/HEAD UP FOR PRIDE as productive conceptual mappings in English.
} 
4) Nema stida, srama... a trebalo bi da bude manja od makova zrna! ('She has no shame....and she should be smaller than a poppy seed')/Htela sam $u$ zemlju da propadnem ('I wanted to sink into the ground')

As shown above, in the case of the concepts more closely denoting an overweening opinion of oneself, the experiencer is caricatured as unnaturally big/ swollen, exceeding one's proper size, or trying to position him/herself in the upper regions of the vertical scale or above other people ${ }^{7}$.

While some of the above expressions are obvious instantiations of body-based metonymies, reflecting the bodily behaviour that typically accompanies pride and shame, as well as the metaphor INTENSITY IS SIZE, it can be argued that in the case of self-conscious emotions, such conceptualization is intimately related to the primary metaphor IMPORTANT IS BIG/UNIMPORTANT IS SMALL, which is involved in the construction of the antecedent cognitive processes that generate self-conscious emotions - namely, the thoughts 'I am (un)important/(un)worthy' (see Broćić 2014; for a more detailed account of how a number of these expressions can be interpereted as evidence of the interplay between metaphor and metonymy see Broćić 2014, 2018a: 432-447).

\subsection{The овJECT metaphors}

Similarly, within the generic-level OBJECT metaphors, the construal of PRIDE as A PRECIOUS POSSESSION stands in contrast to that of SHAME as AN UNDESIRABLE OBJECT. More specifically, Broćic $(2018 \mathrm{a}, 2019)$ uses the term the "possession of a precious object" scenario to refer in particular to the elements of 'acquiring', 'possessing', 'losing', 'stealing', 'destroying', 'preserving/defending' and 'returning' a precious object in the structure of PRIDE (or concepts designating self-respect), while SHAME, on the other hand, is characterized by the image of an undesirable object that the experiencer is trying to get rid of (i.e. the skeletal "possession of an undesirable object" scenario).

\footnotetext{
${ }^{6}$ An additional piece of evidence for the existence of the abovementioned metaphors can be found in the studies investigating the American cultural models of pride (Davitz 1969) and shame (Holland and Kipnis 1995), in which the respondents were asked to describe their own feelings of pride, i.e. shame. Among the descriptive statements that the respondents used in connection with pride were "I feel taller, stronger bigger, strong inside; I have a sense of sureness, a sense of being important and worthwhile" (Davitz 1969: 77), i.e. "I felt small. I felt so big (with fingers held an inch apart). I felt so low I could have crawled under a snake's belly" when referring to a sense of shame (Holland and Kipnis 1995).

${ }^{7}$ Coherent with this conceptualization is also the construal of the states referring to excessive pride as objects that are huge, or alternatively a location/container situated in an elevated position (EXCESSIVE PRIDE/EGO IS A HUGE OBJECT, A LOCATION/CONTAINER THAT IS UP), as corroborated by examples such as monumental arrogance, mammoth, gargantuan ego, pushy young fellow with an ego the size of the bullring in English and te sujete veće od Homoljskih planina, nemoguće je okupiti ljude sa tolikim egom u jednu sobu, biti uznet u sujeti, sići sa vrha kule svoje oholosti in Serbian.
} 
However, close inspection of pertinent examples shows that this contrast exists at a high level of generality as the specific-level metaphors are characterized by a unique elaboration of the metaphorical "possession of the object scenario". Furthermore, the metaphorical conceptualization of PRIDE and SHAME via these OBJECT metaphors differs with respect to the salience of the specific constitutive submappings within the abovementioned generic-level scenarios.

Namely, within the domain of PRIDE, the findings point to the prominence of the elements of 'destruction', 'theft/loss' and 'defence/preservation', as evidenced by a wide range of diverse linguistic realizations of the submappings tHE (FIGURATIVE) LOSS OF PRIDE IS LOSS OF PRIDE/OBJECT, PRIDE/SELF-RESPECT IS AN OBJECT VULNERABLE TO THEFT and JEOPARDIZING ONE'S FEELING OF PRIDE IS CAUSING PHYSICAL DAMAGE TO HIS/HER PRIDE-(VALUABLE) OBJECT and PRIDE/SELF-RESPECT IS A VALUABLE OBJECT WHICH HAS TO BE PRESERVED AND DEFENDED in both languages, e.g. E: lose, steal, dent, shatter, batter, break one's pride, undermine, damage, destroy, bombard, trample (on) one's selfrespect, dignity, salvage, protect one's pride/self-esteem; S: izgubiti ponos (to lose pride), Gubitnici ..časti, dostojanstva (losers of honour, dignity)/(brutalno) oduzeti, ukrasti, uzeti nekome, ponos, dostojanstvo/ lišiti nekoga dostojanstva (to steal, take one's pride dignity, pride; to strip sb of dignity), uništiti (nacionalni) ponos (destroy (national) pride), vršiti napad na/mučki udar na nečije dostojanstvo, atakovati na nečije dostojanstvo (a savage attack on one's dignity), sačuvati/odbraniti obraz, ponos, dostojanstvo. It is also noteworthy that such expressions more often than not carry dramatic overtones and can be said to be emotionally resonant, particularly in the case of collective pride and dignity:

$\mathrm{E}$ :

5) His pride...was shattered

6) War on drugs as a frontal assault on a worker's dignity

S:

7) Unakazivanje osećaja nacionalnog ponosa 'the mutilation of national pride'

8) Mučki udar na kulturu i dostojanstvo srpskog naroda ' a savage attack on the culture and dignity of the Serbian people'

On the other hand, the element of 'acquiring/coming into possession', i.e. the first element of the scenario in the domain of SHAME is elaborated in the following way: shame/guilt-object is construed as an object that is forced on/foisted on the Emoter, or

\footnotetext{
${ }^{8}$ For a detailed discussion of the conceptualization of positive self-conscious emotions via "the possession of a precious object scenario" in English and Serbian, as well as some of the culture-specific properties and potentially manipulative aspects of the metaphorical structuring of collective pride, dignity and honour via this scenario in the Serbian language see Broćić (2019).
} 
more specifically, SHAME-AN UNDESIRABLE OBJECT falls on/is brought on/thrown onto, or covers the Emoter, giving rise to the submetaphors SHAME/GUILT IS AN OBJECT THAT IS FORCED ON THE EXPERIENCER and SHAME IS AN OBJECT THAT IS BROUGHT ON/FALLS ON/COVERS THE EXPERIENCER:

$\mathrm{E}:$

9) He has brought shame on the whole family.

10) All the things that can be passed down, the inhibitions, guilt and fear.

11) Satan is interested in bringing misery...suffering...pain... and guilt into our lives.

S:

12) Između njih je pala jedna teška reč koja ih je oboje pokrila stidom.

13) Mene poklopio sram, zna me sprat iznad mene, i ispod.

14) Ono što se dogodilo preživelima holokausta u Poljskoj bilo je duže od pola veka prekriveno velom krivice i srama.

15) Tvoja podlost sramotom pokriva.

16) Zlo i unikum koji se desio samo Crnoj Gori na koju treba da padne najteža sramota.

17) Uspela je da me poljubi...obriše svoj karmin s mog obraza i nametne mi osećaj krivice.

18) ...roditelji nasledniku „nabacuju” ogromno osećanje krivice.

19) Taj stari, porodični trik da se deci naturi osećanje krivice, nažalost, još uvek je u modi..

The Serbian data indicate (e.g. examples $12,14,15$ ) that shame can be further specified in Serbian as a less prototypical object, for instance, a textile, which in turn motivates linguistic expressions such as prekriti, pokriti sramom/sramotom, prekriti velom krivice $i$ srama ${ }^{9}$. In addition, the examples in which the Serbian nouns (pronouns) denoting the experiencer are used in the accusative case suggest that shame can be construed as AN OBJECT DIRECTLY HITTING THE EXPERIENCER ${ }^{10}$ :

\footnotetext{
${ }^{9}$ Generally, the findings point to a more refined and elaborate metaphorical substructure pertaining to the element of 'coming into possession' in Serbian compared to English, as corroborated by a wider range of the linguistic realizations of the pertinent submetaphor in Serbian (eg. sram/stid/sramota pokriva, prekriva, poklapa, pada na subjekta etc.)

${ }^{10}$ Based on the available characterizations of the case system in Serbian (e.g. Stevanović 1989; Antonić 2005), Bogetić, Broćić and Rasulić (2019) identified two basic senses of the accusative case: 1) affected object of physical action (polomili su prozor 'they broke the window') and 2) object of perception, emotion, cognition (videti kuću 'to see the house'). It can thus be argued that in examples such as 'sramota/stid me $j e$ ' A SENSE OF SHAME and THE EXPERIENCER are conceptualized as AN OBJECT HITTING THE EXPERIENCER and THE AFFECTED OBJECT OF PHYSICAL ACTION respectively, highlighting the intensity of shame as well as the experiencer's preoccupation with it.
} 
20) Sramota me je

shame I-ACC.SG is

'I am ashamed of myself'

Furthermore, the most salient specific-level object metaphor structuring SHAME and GUILT in both languages is SHAME IS A BURDEN, i.e. GUILT IS A BURDEN ${ }^{11}$, while guilt can additionally be conceptualized as A SHARP OBJECT; this conceptualization can be said to be maximally coherent with the aforementioned image of shame as an object that falls on, is thrown onto, and is consequently located on top of the subject:

E:

21) The shame, the guilt, the remorse were weighing heavily upon the parents.

22) To rid one's self of the continuing sole burden of shame and guilt.

23) She told me you left the station because someone arrived who could let your secrets out, and you couldn't bear the shame.

24) Deepest guilt lies heavy on the shoulders...

25) Rory cried, feeling the weight of guilt settle on her shoulders like a suffocating cloak...

26) The intolerable pressure of guilt that would inevitably descend like a black mantle over even the most vulgar and sensual head.

27) Hiding from others may save face, but at the cost of an increased weight of private guilt.

28) A young man from Glasgow, who seemed to bear on his narrow shoulders guilt for all the sins of the Western world.

29) She refused to acknowledge the twinge of guilt that prodded her.

30) She felt a sudden stab of guilt, comparing him with Jenny.

31) Harriet had experienced a moment's sharp guilt.

32) The once popular Sonja feel the cutting edge of guilt..

33) Revelation went sweetly on, thus impaling me on the hook of my own guilt once more.

S:

34) Ne znam kako ona može nositi taj teret srama.

35) U stvari, njega obrva teški stid pred poniženjem koje mu je ostajalo.

36) Ušunjala sam se u kancelariju, ophrvana stidom zbog poruke.

\footnotetext{
${ }^{11}$ Even though painful and unpleasant emotional states more generally can be conceptualized as BURDENS (e.g. Apresjan 1997; Klikovac 2006[2000]: 194), the conceptualization of SHAME and GUILT via the source domains DOWN and BURDEN differs from that of other undesirable emotions via the same domains insofar as it is also based on the mappings IMMORAL IS DOWN, as formulated by Rasulić (2004), and, particularly RESPONSIBILITY IS A BURDEN (Kövecses 1986: 26; Deignan 1999), thereby indicating that the distinctive features of metaphoric conceptualization may also find their expression in the form of unique conceptual motivation.
} 
37) Napregnutost se prekide i pritište je stid.

38) Ta kuća se...uspešno oslobađa teškog bremena bruke i srama koji je pao na njena pleća..

39) Onaj ko je ubio, poneće pred Bogom breme svoje krivice.

40) Izvesna akušerska sestra u penziji osetila toliki teret krivice jer se prisetila svog zločina...

41) „Creation” prikazuje čuvenog naučnika kao posvećenog porodičnog čoveka, koji se muči pod teretom krivice jer sebe smatra odgovornim za ćerkinu smrt.

42) Da li njegov super-ego - ako ga ima - može da podnese toliku količinu zločina, a da se ne slomije pod osećanjem krivice?

43) Prošlost...kao kaiš za oštrenje krivice i strahova.

What emerges from the present analysis, therefore, is that pride and shame are not construed via pairs of opposing metaphors at the level of specific elements, e.g. we do not get SHAME IS A HEAVY OBJECT as against PRIDE IS A LIGHT OBJECT.

It is also noteworthy that the findings point to a more dynamic metaphorical conceptualization in the domain of SHAME in the sense that the reified emotion literally comes into physical, or more specifically, forcible (physical) contact with the Emoter - as shown above, this contact can take the form of a burden exerting physical force on, an object hitting, or a sharp object prodding the experiencer. The images evoked by some of the linguistic data can be represented visually in the following way:
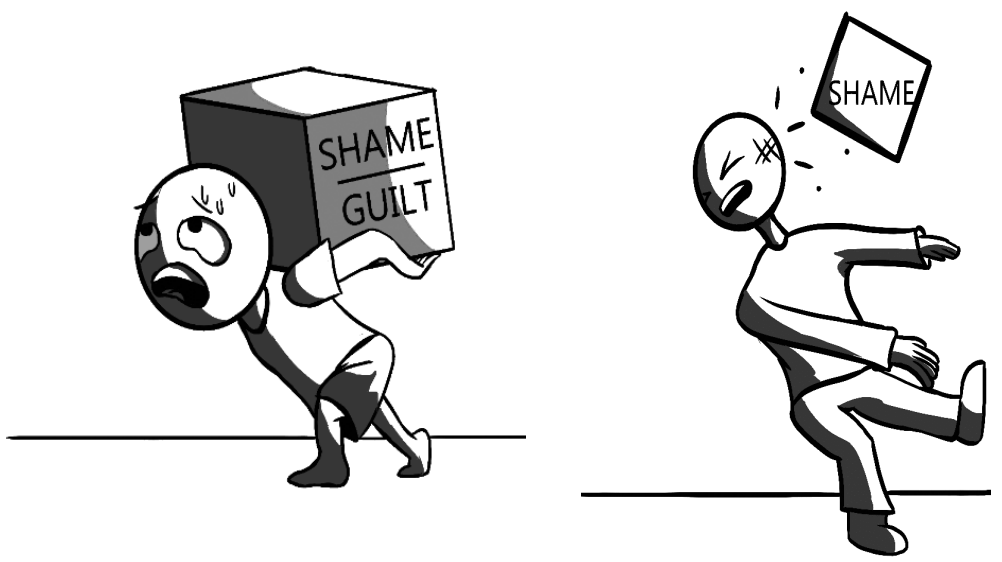

In the light of this, it can be concluded that, compared to pride metaphors, the metaphors structuring shame exhibit a higher degree of entrenchment in the body insofar as they are fundamentally grounded in the more basic conceptual mappings, namely, MENTAL/EMOTIONAL PAIN (SUFFERING) IS PHYSICAL PAIN (or SOCIAL (OR PSYCHOLOGICAL) 
HARM IS PHYSICAL HARM, as formulated by Lakoff 1987: 448), which is ultimately built on the MIND-AS-BODY metaphor (Sweetser 1990), EMOTIONAL DISTURBANCE IS PHYSICAL DISTURBANCE (Kövecses 2007), PROGRESS IS MOVING FORWARD or the BALANCE schema (Johnson 1987), seeing as the reified emotion knocks the experiencer off balance by putting pressure on him.

\subsection{The SUBSTANCE metaphors}

The findings point to an absence of opposing elements within the most salient SUBSTANCE metaphors. For instance, whereas PRIDE IS LIGHT ${ }^{12}$ is the second most frequent substance metaphor in both samples, imparting a highly positive evaluation to pride, shame is not associated with darkness:

$\mathrm{E}:$

44) A warm glow of pride settled itself whenever she thought about it.

45) She can twist me round her little finger, is said with glowing pride.

46) Love and pride shone from her enormous black eyes.

S:

47) Zatim će ga obasjati roditeljski ponos.

48) Otac ga gledaše sa bolnim i blistavim ponosom.

49) Seća se svoje jazbine...s nekim svetlim ponosom.

Moreover, we do not get the HEAT-COLD contrast, but both pride and shame can be conceptualized via the domain of HEAT and its lower-level instantiations (FIRE, A BOILING FLUID IN THE BODY-CONTAINER, A DELIBERATELY HEATED SUBSTANCE). Interestingly, however, a closer look at their linguistic realizations demonstrates that these metaphors differ with respect to their meaning foci and experiential bases ${ }^{13}$ :

E:

50) Their burning pridel to rekindle pride

51) Scalded by shame

52) Shame rose in a hot wave, governing her actions, defying caution

53) Shame burned within her

S:

54) Ponos koji se razbuktao za vreme rata 'pride which flared up during the war'

55) Podgrejavaju nacionalni ponos na neuralgičnom pitanju 'They are heating national pride on this sensitive issue'

\footnotetext{
${ }^{12}$ According to Klikovac (2006[2000]: 43), light can be regarded as a non-prototypical member of the SUBSTANCE category.

${ }^{13}$ A fine-grained analysis of the ways in which PRIDE and SHAME are structured via the source domains HEAT and COLD in English and Serbian can be found in Broćić (2018a, 2018b).
} 
56) Ova uvrežena teorija sveta [...] uvek iznova samo potpaljuje nacionalni ponos 'This widespread theory of the world repeatedly ignites national pride'

57) Pekao ju je stid 'Shame scalded her'

58) Umirem od stida i od ognja koji me sagoreva 'I'm dying of shame and the flame that is devouring me'

59) Razdirana...plimama plamtećeg stida 'torn apart by tides of blazing shame'

Based on the above examples, it becomes obvious that PRIDE IS HEAT foregrounds the intensity of pride (examples 50,54), as well as the potential of pride to incite the subject to violence, as corroborated by the particular choice of lexemes in examples (55) and (56) and the wider context in which they are embedded. SHAME IS HEAT, by contrast, accentuates the emotional suffering caused by a feeling of shame in addition to the intensity of this unpleasant emotion.

As was the case with the SHAME-OBJECT metaphors, the choice of metaphorical expressions in both languages serves to conjure up images of shame as an overwhelming heat-force/flame burning through, scalding or engulfing the experiencer - that is to say, SHAME-HEAT, unlike PRIDE-HEAT, causes immense physical damage to the experiencer, and not to his/her surroundings, thereby indicating that the metaphor SHAME IS HEAT is fundamentally entrenched in the more basic MENTAL/EMOTIONAL PAIN (SUFFERING) IS PHYSICAL PAIN metaphor.

\subsection{The ANIMATE ENTITY metaphors}

Within the conceptualization of these states as animate entities we do not find, for the most part, either the corresponding or contrasting elements. For instance, the image of wounding and hurting a being/human (i.e. JEOPARDIZING ONE'S PRIDE IS WOUNDING/HURTING/INSULTING PRIDE-BEING/HUMAN) is restricted to the domain of positive self-evaluation emotions, while excessive pride is associated with the image of both the physical and psychological pampering of a being/human (i.e. BOOSTING ONE'S EGO/ (EXCESSIVE) PRIDE IS PAMPERING (FlatTERING, FEEDING, MASSAGING) EGO-A BEING /huMAN, EGO IS A VORACIOUS BEING). The findings also indicate a high level of productivity of the conceptual mechanism referred to in Broćić (2018a) as "the synergy of metaphor and metonymy", featured most prominently in the conceptual structure of pride and excessive pride, whereby we attribute emotional responses and behaviour evoked by these states to the states themselves (see e.g. 62, 63, 64, 67, 68, 73, 76, 78). The abovementioned conceptual mechanisms can be illustrated with the following examples:

E:

60) The American sat there, mouthed a few more obscenities as he nursed his hurt pride. 
61) My apologies, she grinned, aware that she's wounded his massive ego.

62) It seemed a gross insult to Elf pride.

63) 'I hear you!' she retorted, her pride up in arms.

64) My pride suddenly felt better.

65) But Altman's biggest victims, you sense, are ordinary Joes like you and I who feed the arrogance of these dreamworld fat cats.

66) ...his vanity was fed the magical words of 'Foreign and Commonwealth Office'

$67)$ Is it their arrogance that presumes such greatness?

68) The Ego does charitable work in order to pat itself on the back.

69) Pride gets in the way of race relations.

$\mathrm{S}$ :

70) Time je svakako povređen naš nacionalni ponos.

71) Ova pogrdna demoralizacija, koja ubija ponos i dostojanstvo crnogorskog naroda.

72) Ulogu je igrala i povređena sujeta.

73) Sav njegov ponos morao se pobuniti protiv takvog srodstva.

74) Ego je morao da mu bude sit.

75) Ona je hranila njegovu oholost.

76) Sujeti svakog autora, pa i mojoj, prija kada se vidi da su njegovi filmovi još uvek živi.

77) Dodvoravalo se ljudskoj sujeti.

78) Sujeta generala Fabija Kontija kupila je jednu zemlju od preko tri stotine hiljada franaka.

On the other hand, both PRIDE and SHAME can be conceptualized as SOCIAL SUPERIORS (GOVERNING OUR BEHAVIOUR) and OPPONENTS IN A STRUGGLE:

$\mathrm{E}$ :

79) Her pride refused to let her ask him why he found her company so amusing.

80) Pride - and honour - demanded one thing of her.

81) Pride had decreed she should put on her best white silky dress.

82) Vanity compelled us to try.

83) We're dominated by ego here.

84) Was his vanity really so overpowering?

85) Vanity as always prevailed.

86) Embarrassment at her own state of undress forced her to make a grab for the material.

87) A natural sense of shame forbade them to recognize... 
88) She felt quite overcome with shame

89) Shame and guilt tormented the innocent more than the wicked.

90) His shame at...seems to have unhinged him.

91) It is often guilt or fear that stops us from telling the truth.

92) Victim of guilt

93) Guilt besieged him for many years.

94) Grief gave way to a guilt which gnawed at him.

95) The same mixture of guilt and hate and sorrow would strike anew.

96) The guilt took her in its fist and squeezed.

$\mathrm{S}$ :

97) Njihov ponos i samosvest zabranjuje im da obleću oko gostiju iz grada.

98) Služim daleko većem gospodaru nego što je moj ponos.

99) Znao je da mu gordost to neće dopustiti.

100) Njihova ogromna sujeta zahteva da se to na neki način vizuelno izrazi.

101) Vi ste rob oholosti.

102) Strasna želja mu je grizla srce da savlada ponos.

103) Naši su se vođi borili protiv sopstvenih sujeta i pohlepe.

104) Vera štiti čoveka od...sujete, egoizma

105) Cilj posta je da pobedimo egoizam, gordost, samoljublje

106) Borba protiv najopasnijeg greha u kome, kao majci grehova, nalazi se gordost.

107) Već deset godina stid ju je sprečavao da se nekome ispovedi.

108) Ćutanje i stid su ubice koliko i sama bolest.

109) U tom času njenu dušu opet kidaju gnev, žalost i stid.

110) Ali voda ne utiša strašno osećanje stida koje ga je držalo za gušu.

111) Živ sram da te pojede.

112) Osećanje krivice prisiljava na ispravljanje greške.

113) Lois se bori sa osećanjem krivice.

114) Čije roditelje razara sasvim iracionalna krivica

115) Krivica ga je izjedala

116) Prvo te udari osećanje krivice.

While both pride and shame can be construed as OPPONENTS IN A STRUGGLE, close inspection of some of the pertinent examples relating to the SHAME domain reveals that the images evoked are often those of an opponent in a struggle violently attacking the subject - as shown above, shame and guilt can be construed as entities which can cripple, torment, unhinge, strike, gnaw at, squeeze (e.g. 90, 94, 95, 96, 109, 110, 111, $114,115,116)$, i.e. cause severe physical damage to the experiencer - which is in turn 
further confirmation of a higher degree of the entrenchment of the shame metaphors in bodily experience.

\section{Discussion and concluding remarks}

The corpus-based analysis presented in this paper has shown that emotions such as pride and shame are only rarely structured via pairs of opposing metaphors ${ }^{14}$. Admittedly, the metaphors based on the aforementioned UP/BIG-DOWN/SMALL opposition represent a prime example of pride/shame - specific metaphors (structuring self-conscious emotions pride and shame in a unique way) since they characterize a necessary and sufficient feature of the category of self-conscious emotions, namely a sense of personal worth (or lack thereof), from which these emotional states essentially originate ${ }^{15}$. That may be the reason that we perceive them as opposing emotional experiences, and the corresponding metaphorical conceptualization reflects this contrast.

Furthermore, contrasting elements (regarding metaphorical conceptualization) pertain to an aspect that has to do with whether we perceive certain emotional states as inherently pleasant or unpleasant and the construal of pride as A PRECIOUS POSSESSION versus that of shame as AN UNDESIRABLE one is indicative of this contrast. We can set up a hypothesis that the VALUABLE-UNDESIRABLE OBJECT opposition at a high level of generality will always be present when our emotional experiences are construed from the perspective of the Emoter.

But generally, the findings imply that antonymous emotion concepts by and large tend to be characterized by an independent and unique metaphoric conceptualization and elaboration of generic-level metaphors (particularly regarding specific-level metaphors). In relation to this point, it can be concluded that such an independent metaphoric conceptualization is essentially determined by the elements that are particularly foregrounded in the structure of specific emotion concepts. For instance, a sense of responsibility (for a misdeed) being intrinsic to guilt results in SHAME/GUILT being predominantly construed as A BURDEN, while the salience of the DESTRUCTION and DEFENCE metaphors in the structure of pride and self-respect focuses on the fragility of these states and our need to constantly reaffirm our sense of personal worth and pride.

\footnotetext{
${ }^{14}$ In this respect, these results are similar to those reported by Stefanowitsch (2006) regarding the conceptualization of HAPPINESS and SADNESS in English.

${ }^{15}$ While it can be argued that a sense of personal worth constitutes a necessary and sufficient attribute of the category of self-conscious emotions, this category - or more specifically, the category of pride, i.e. shame - has a complex internal structure with fuzzy boundaries, meaning that its structure and organization can only adequately and fully be accounted for in line with the principles of the prototype approach to categorization (see Broćić 2018a: 487-492).
} 
Also, the role of perspective is crucial to the way we conceptualize emotions, as evidenced by the use of hyperbole and elements of caricature in the linguistic realizations of the metaphor TO BE EXCESSIVELY PROUD IS TO BE UNNATURALLY BIG, which testifies to the fact that an element of social denouncement is built into such conceptualization and that these states are construed from the Observer's perspective. The distinctive features of metaphoric conceptualization can additionally be determined by the domain/frame in which an emotion concept is profiled - for example, excessive pride is (more often than not) profiled against the domain of Christianity, when conceptualized as AN OPPONENT IN A STRUGGLE (e.g. 104, 105, 106).

Overall, the analysis has shown that the intricacies and complexities of metaphoric conceptualization cannot be reduced to mere binary oppositions even in the case of (emotion) concepts that are perceived as opposites. Furthermore, it has once again demonstrated that the study of metaphors can be fruitfully applied to the investigation of the multifaceted nature of emotion concepts since conceptual metaphors reflect the subtleties and nuances of our folk theories of emotions that evade simple definitions.

\section{References}

Antonić, I. (2005). Sintaksa i semantika padeža. In: P. Piper et al. (eds.), Sintaksa savremenoga srpskog jezika. Prosta rečenica. Beograd: Institut za srpski jezik SANU/Beogradska knjiga/Matica srpska, 119-300.

Apresjan, V. (1997). Emotion Metaphors and Cross-Linguistic Conceptualisation of Emotions. Cuadernos de Filología Inglesa, 179-195.

Bogetić, K., A. Broćić and K. Rasulić (2019). Linguistic metaphor identification in Serbian. In: S. Nacey, A. G. Dorst, T. Krennmayr and W. Gudrun Reijnierse (eds.), MIPVU in Multiple Languages, Amsterdam: John Benjamins, 204-226.

Broćić, A. (2014). On the role of verticality and size in the conceptualization of selfreflective Emotions. In: Z. Paunović, M. Daničić, B. Gledić and J. Matić (eds.), ELLSEE Proceedings, Belgrade: Faculty of Philology, 91-103.

Broćić, A. (2018a). Konceptualizacija emocija samovrednovanja u engleskom $i$ srpskom jeziku. Unpublished PhD dissertation. Faculty of Philology, University of Belgrade.

Broćić, A. (2018b). The Conceptualization of PRIDE and SHAME in English and Serbian via the Temperature Domain. In: Z. Kašić (ed.) Primenjena lingvistika u čast Vesni Berić-Đukić - ojeziku sa raznih aspekata, Novi Sad and Beograd: Društvo za primenjenu lingvistiku Srbije, Filozofski fakultet Univerziteta u Novom Sadu, Filološki fakultet Univerziteta u Beogradu, 49-64. 
Broćić, A. (2019). Pride as a metaphorical treasure: the conceptualization of PRIDE and SELF-RESPECT in English and Serbian via 'the possession of a precious object' scenario'. Belgrade English Language and Literature Studies, XI, 11-43.

Davitz, J. (1969). The language of emotion. New York: Academic Press.

Deignan, A. (1999). Corpus-based research into metaphor. In: L. Cameron and G. Low (eds.), Researching and Applying Metaphor, Cambridge: Cambridge University Press, 177-199.

Dziwirek, K. and B. Lewandowska-Tomaszczyk (2010). Complex Emotions and Grammatical Mismatches: A Contrastive Corpus-Based Study. Berlin and New York: Mouton de Gruyter.

Grady, J. (1999). A Typology of Motivation for Conceptual Metaphor: Correlation vs. Resemblance. In: R. W. Gibbs and G. Steen (eds.), Metaphor in Cognitive Linguistics, Philadelphia: John Benjamins, 79-100.

Holland, D. and A. Kipnis (1995). The not-so-egotistic aspects of American self. In: J. A. Russel et al. (eds.), Everyday conceptions of emotion, Dordreht: Kluwer, 181-202.

Johnson, M. (1987). The Body in the Mind: The Bodily Basis of Meaning, Imagination, and Reason. Chicago: University of Chicago Press.

Klikovac, D. (2004). Metafore u mišljenju i jeziku. Beograd: XX vek.

Klikovac, D. (2006[2000]). Semantika predloga - Studija iz kognitivne lingvistike. 2. izdanje. Beograd: Filološki fakultet.

Kosanović, M. (2009). Konceptualizacija emocije sreće u engleskom i srpskom jeziku. Unpublished MA thesis. Faculty of Philology, University of Belgrade.

Kosanović, M. (2016). Pridevi koji označavaju emocije u engleskom i srpskom jeziku: kognitivnolingvistička analiza. Unpublished $\mathrm{PhD}$ dissertation. Faculty of Philology, University of Belgrade.

Kövecses, Z. (1986). Metaphors of Anger, Pride, And Love: A Lexical Approach to the Structure of Concepts. Amsterdam and Philadelphia: John Benjamins.

Kövecses, Z. (1998). Are There Any Emotion-Specific Metaphors? In: A. Athanasiadou and E. Tabakowska (eds.), Speaking of Emotions: Conceptualization and Expression, Berlin and New York: Mouton de Gruyter, 127-151.

Kövecses, Z. (2000). Metaphor and Emotion. Language, Culture, and the Body in Human Feeling. Cambridge and New York: Cambridge University Press.

Kövecses, Z. (2005). Metaphor in Culture. Universality and Variation. Cambridge: CUP.

Kövecses, Z. (2007). Emotion concepts: from happiness to guilt: A cognitive semantic perspective. (15 October 2019) <https://www.researchgate.net/ publication/299468588_Emotion_concepts_from_happiness_to_guilt_A_ cognitive_semantic_perspective_1>. 
Kövecses, Z. (2008). Metaphor and Emotion. In: R. Gibbs (ed.), The Cambridge Handbook of Metaphor and Thought, Cambridge: Cambridge University Press, 380-396.

Kövecses, Z. (2010[2002]). Metaphor. A Practical Introduction. New York and Oxford: Oxford University Press.

Lakoff, G. (1987). Women, Fire, and Dangerous Things: What Categories Reveal about the Mind. Chicago: University of Chicago Press.

Lakoff, G. and M. Johnson (2003[1980]). Metaphors We Live By. Chicago: University of Chicago Press.

Leary, M. R. (2004). Digging deeper: The fundamental nature of "self-conscious" emotions. Psychological Inquiry, 15(2), 129-131.

Ogarkova, A. and C. Soriano (2014a). Emotion and the Body: A Corpus-Based Investigation of Metaphorical Containers of Anger Across Languages. International Journal of Cognitive Linguistics, 5(2), 147-179.

Ogarkova, A. and C. Soriano (2014b). Variation Within Universals: The 'Metaphorical Profile' Approach to the Study of Anger Concepts in English, Russian and Spanish. In: A. Mussolf, F. MacArthur and G. Pagani (eds.), Metaphor and Intercultural Communication, London: Bloomsbury Academic, 93-116.

Ogarkova, A. and C. Soriano (2018). Metaphorical and Literal Profiling in the Study of Emotions. Metaphor and Symbol, 33 (1), 19-35.

Rasulić, K. (2004). Jezik i prostorno iskustvo. Beograd: Filološki fakultet.

Stefanowitsch, A. (2006). Words and Their Metaphors. A Corpus-Based Approach. In: A. Stefanowitsch and S. Gries (eds.), Corpus-based Approaches to Metaphor and Metonymy, Berlin and New York: Mouton de Gruyter, 63-105.

Stevanović, M. (1989 [1 $1^{\text {st }}$ ed. 1964]). Savremeni srpskohrvatski jezik I-II. Beograd: Naučna knjiga.

Sweetser, E. (1990). From Etymology to Pragmatics: Metaphorical and Cultural Aspects of Semantic Structure. Cambridge: Cambridge University Press.

Tangney, J. P. and K. W. Fischer (eds.) (1995). Self-conscious emotions: The psychology of shame, guilt, embarrassment and pride. New York, NY: Guilford Press.

Tracy, J. L. and R. W. Robins (2004). Putting the self into self-conscious emotions: A theoretical model. Psychological Inquiry, 15, 103-125.

\section{Sources}

BNC: British National Corpus. (15 October 2019) <http://corpus.byu.edu/bnc $>$.

KSSJ: Korpus savremenog srpskog jezika [Corpus of the contemporary Serbian language]. Matematički fakultet, Univerzitet u Beogradu, 2013. (15 October 2019) <http://www.korpus.matf.bg.ac.rs> . 